\title{
Immediate effects of an approach in high cervical and occipitomastoidon postural control and mobility of individuals with parkinson's disease: case series
}

\section{Efeitos imediatos de uma abordagem em cervical alta e occipitomastóide no controle postural e mobilidade dos indivíduos com doença de parkinson: série de casos}

\author{
Alexandre Rodrigues Severo', Mateus Corrêa Silveira², Carlos Bolli Mota ${ }^{3}$, Eduardo Costa Rhoden ${ }^{4}$, \\ Nadiesca Taisa Filippin ${ }^{5}$
}

\begin{abstract}
Introduction: Parkinson's disease (PD) causes impairments in postural control and mobility that affect the individual's independence. Manual therapy has been used in the treatment of these disorders and can change mobility and postural control. Objective: To assess the immediate effects of an approach in high cervical and occipitomastoid on postural control and mobility of individuals with PD. Method: Three individuals with PD, females, aged 52 to 73 years, participated in this case series. Participants were assessed immediately before and after therapeutic intervention through releases of suboccipital muscles and occipitomastoid sutures. Trunk mobility, functional mobility and postural control (center of pressure parameters - COP) were evaluated. Results: All participants demonstrated improvements in trunk mobility. Participants 1 and 2 slightly improved functional mobility. Participants 1 and 2 showed a decrease in the medial-lateral displacement of the COP. All participants showed increases in at least one direction to the limits of stability. Conclusions: The results showed that the intervention appears more effective on trunk mobility. Variables related to postural control changed with no consistent pattern. Further studies could investigate the association of other manual therapy techniques and their effects on mobility and postural control in individuals with PD.
\end{abstract}

Keywords: Parkinsonism disorders; Postural balance; Mobility; Musculoskeletal manipulations.

\section{RESUMO}

Introdução: A doença de Parkinson (DP) provoca prejuízos no controle postural e mobilidade, interferindo na independência dos indivíduos. A terapia manual vem sendo utilizada no tratamento dessas desordens podendo promover alterações sobre a mobilidade e controle postural. Objetivo: O objetivo do estudo foi avaliar os efeitos imediatos de uma abordagem em cervical alta e occiptomastoidea sobre o controle postural e mobilidade de indivíduos com doença de Parkinson. Método: Três indivíduos com DP, gênero feminino, idade entre 52 e 73 anos, participaram dessa série de casos. As participantes foram submetidas à avaliação da mobilidade do tronco, mobilidade funcional e controle postural (medidas do centro de pressão - COP) imediatamente antes e após uma intervenção terapêutica na região suboccipital, através de liberações da musculatura suboccipital e suturas occiptomastoidea. Resultados: Todas as participantes obtiveram melhora na mobilidade de tronco. As participantes 1 e 2 melhoraram discretamente a mobilidade funcional. Na avaliação do controle postural as participantes 1 e 2 apresentaram diminuição no deslocamento médio-lateral do COP. Quanto aos limites de estabilidade, todas as participantes apresentaram aumento em pelo menos uma direção. Conclusão: Os resultados indicam que a terapia aplicada parece ter sido mais efetiva sobre a mobilidade de tronco e alterações, sem um padrão consistente, nas variáveis relacionadas ao controle postural. São necessários novos estudos relacionados ao tema, considerando a associação de outras técnicas de terapia manual e identificando seus efeitos sobre a mobilidade e controle postural de indivíduos com DP.

Palavras-chave: Parkinsonismo; Equilíbrio postural; Mobilidade; Manipulação musculoesquelética.

Corresponding author: Nadiesca Taisa Filippin. Rua Silva Jardim, 1175, Centro, Zip Code: 97010-491, Santa Maria (RS), Brazil. Phone: (55) 3317-0112.

E-mail: nadifilippin@yahoo.com.br

${ }^{5}$ Physical Therapy Department, Centro Universitário Franciscano (UNIFRA), Santa Maria (RS) Brazil.

Full list of author information is available at the end of the article.

Financial support: None.

Submission date 06 December 2015; Acceptance date 26 February 2016; Publication date 09 March 2016 


\section{INTRODUCTION}

Brain imaging studies in individuals with Parkinson's disease (PD) have shown that due to loss of dopaminergic cells there is hyperactivation in the cerebellum and primary motor cortex. The hyperactivation in the cerebellum is a compensatory strategy for the defective basal ganglia and the hyperactivation in the primary motor cortex is directly related to upper limb rigidity. ${ }^{(1-7)}$

Intracranial tissue irritation occurs as a consequence of this hyperactivation. The tissues suffer increases in collagen production, which consequently leads to increased tissue tension. ${ }^{(3,8-10)}$ Therefore, reflex changes in the suboccipital region occur in a cascade leading to damage of all muscle groups of the axial skeleton, ${ }^{(10-15)}$ and as a result, impairment in postural control and mobility. Furthermore, these individuals lose functional independence on account of the axial skeleton and thus are at a disadvantage in the face of environmental challenges. ${ }^{(10,16-23)}$

Careful evaluation of these aspects becomes important as well as the development and application of treatment strategies to the specific characteristics of PD. In this way, manual therapy especially in the axial skeleton has been used to treat individuals with mobility and postural control disorders as well as head and neck disorders. ${ }^{(24)}$ Kamali and Shokri ${ }^{(25)}$ reported numerous physiological and functional results using pompages for the decrease or normalization of muscle tone. Liem ${ }^{(26)}$ described that the release techniques of sutures in the occipitomastoid region causes a decrease in muscle tone in the suboccipital region, indicating that the manipulation of dysfunctional areas in the cervical spine can produce modification in the somatosensory process and, consequently, can promote changes in mobility and postural control.

Thus, it may be important to know the effect of an approach related to manual therapy for functional treatment planning of these individuals. Studies have shown evidence of the improvement in some aspects of PD by neurofunctional physical therapy but the effect of manual therapy techniques has not been established. It is important to note that no study has yet investigated changes in mobility, static postural control and limits of stability of individuals with PD after manual therapy techniques in the cervical region. Therefore, the purpose of this study was to assess the immediate effects of an approach in high cervical and occipitomastoid on postural control and mobility of individuals with PD.

\section{CASE REPORT}

\section{Participants}

Fifteen people expressed interest and three people were screened for eligibility. The convenience sample consisted of women with a clinical diagnosis of idiopathic PD, aged between 50 and 80 years, absence of cognitive impairments (Mini Mental
Status Examination - MMSE), modified Hoehn and Yahr (H-Y) stages $2.5-4$, and capacity to ambulate independently. ${ }^{(27,28)}$

Exclusion criteria included uncorrected visual deficit, other neurologic problems, musculoskeletal, cardiovascular or respiratory disease that could pose a risk and interfere in the accomplishment of the evaluation and intervention, use of assistive devices; individuals with a history of intracranial hemorrhage and brain aneurysm or did not agree to participate in the study. ${ }^{(26)}$

This study was approved by the Human Research Ethics Committee (CAAE: 24759213.8.0000.5306) and all subjects gave their written informed consent prior to entering the study.

\section{Outcome measures}

Baseline and post-intervention measures were taken for all participants. Cognitive function was measured using the Mini-Mental State Examination (MMSE), according to educational level. Scores below eighteen indicated cognitive impairment. ${ }^{(27)}$ The modified $\mathrm{H}-\mathrm{Y}$ scale was used to assess the disability degree of participants. ${ }^{(28)}$ Both instruments were used as inclusion criteria in the study. All participants were submitted to an evaluation that consisted of personal data collection, anthropometric measurement and clinical characteristics. Mobility scales and assessment of postural control were used to identify the immediate effects of the intervention.

Mobility was measured by using the Trunk Impairment Scale (TIS), Trunk Mobility Scale (TMS) and Timed Up and Go (TUG) test. TIS evaluates static (SSB) and dynamic sitting balance (DSB) and trunk coordination (CO). The maximum score is 23 points. ${ }^{(15,29)}$ TMS is based on six dynamic tests that involve the trunk movements in the sagittal, transversal and coronal planes and one static test that evaluated the sitting posture. Scores of dynamic items range from 0 to $3 .{ }^{(30)}$ TUG test assesses functional mobility and it is timed for three trials. ${ }^{(31)}$

A force plate AMTI OR6-6-2000 (Advanced Mechanical Technologies, Inc.) recorded the center of pressure (COP). The data were collected at a sampling rate of $100 \mathrm{~Hz}$. Each participant stood barefoot on the force plate, with feet at a self-selected distance and standardized on the first trial, looking straight one meter ahead, with their hands at their sides. First, three successful trials in static position lasting 30 seconds (s) each were collected. COP variables analyzed in this position were anterior-posterior (AP) and medial-lateral displacement $(\mathrm{ML})$, total velocity and $95 \%$ confidence ellipse area.

Then, the limits of stability (LOS) through the lean forward, backward, right and left were assessed. Three successful trials in each condition, lasting $30 \mathrm{~s}$ each were collected, totaling 12 trials. In each condition, the participants were asked to lean in the corresponding direction as far as possible and maintain that position for the duration of the trial (30 s). They were encouraged to use the ankle strategy without lifting their toes and heels of the support surface. The sequence for the 
leaning was randomized. The smaller the distance between the COP and the edge of the foot $(\mathrm{cm})$, the higher the LOS. An experimenter was always standing near the participant for safety purposes. Familiarization trials were conducted prior to data recording. Rest periods were provided between trials as needed.

Immediately before and immediately after intervention the mobility and the postural control (COP parameters) were assessed. Before and after the evaluations, measures of blood pressure, heart and respiratory rates were recorded.

\section{Intervention}

The single intervention consisted of three moments as follows. First, the participant was asked to lie in supine with limbs relaxed. The therapist sitting at the head of the table held the pompage technique (suboccipital decompression with the purpose of release of the suboccipital muscles) and placed both hands underneath the occiput with the palms facing anterior. The participant's head rested on the therapist's palms. The therapist bended their fingers upward at a right angle so that they were pointing directly anterior, immediately by the inferior palpable border of the occiput, very close to the arch of the atlas. The weight of the skull alone, with the therapist's fingers acting as a lever, was used to release the nuchal muscles, not requiring additional pressure. During the course of the intervention, when the nuchal muscles relaxed, the therapist's fingers rested on the posterior arch of the atlas. The breathing of the participant was normal. ${ }^{(9,26,32)}$

In a second moment, the intervention occurred with release of occipitomastoid (OM) suture. The participant laid in supine with head slightly tilted to the side approached. The therapist sitting at the head of the table placed the index and middle fingers (in " $V$ " format) of the ipsilateral hand from one part to another of OM suture. The contralateral hand was placed over the frontal bone, opposed to OM suture. For suture decompression, a separation between the index and middle fingers by means of a skin grip (compression) was necessary. The frontal hand exerted pressure directed to the OM suture. This pressure lasted $3 \mathrm{~s}$, followed by $3 \mathrm{~s}$ of relaxation. The strength of this pressure was not excessive, rather, it caused a sensation of plasticity associated with the pace of the maneuver. ${ }^{(9)}$

Lastly, the ear-pull method was used. The therapist sat at the head of the supine participant, placed each thumb pad into an ear at the antihelix, with the index and middle fingers in opposition to the thumbs on the posterior surfaces of the external ear, as close as possible to the temporal bones. The therapist grasped the antitragus and lobe of each ear with the thumb and fingers and applied traction in a lateroposterior superior direction. Gently and very slowly, the amount of force was increased. A slightly greater application of force sometimes was necessary to release restrictions of the temporal bone, but this was always kept below the point where the tissue reacted to the force of the traction and contracted against it. ${ }^{(26)}$ At the end of the study a summary of the results was given to participants.

\section{Data analysis}

Postural control variables were processed using the IDL program (Interactive Data Language). Data were filtered using 4th order low pass Butterworth filter with a cutoff frequency of $10 \mathrm{~Hz}$. Mobility data and postural control were analyzed using descriptive statistics (mean and percentage).

\section{PARTICIPANT DESCRIPTION}

\section{Participant 1}

Participant 1 was a 52-year-old woman, with a diagnosis of PD made in 2011, with the right side being the more-affected side of the body. Aside from diabetes mellitus and hypertension diagnosed since 2012, she had no other significant medical history. Throughout the course of this study, PD was medically managed with levodopa and benserazide $62.5 / 250 \mathrm{mg}$, six tablets per day and biperiden hydrochloride $2 \mathrm{mg}$, two times per day.

Participant 1 was retired since 2009 due to her functional decline as a loss of balance and bradykinesia. During the study period, her main responsibilities were home care. She is divorced and has a daughter. She did not require supervision. Her baseline MMSE score was 25 and modified $\mathrm{H}-\mathrm{Y}$ scale was 3.

Participant 1 had difficulty in taking positions on the force plate, used only two moments of rest between trials and she did not have any discomfort during the intervention.

\section{Participant 2}

Participant 2 was a 72-year-old woman, with a diagnosis of PD made in 2011, with her right side being the more-affected side of the body. Aside from a fracture in the left arm in 2012, she had no other significant medical history. Throughout the course of this study, PD was medically managed with levodopa $250 \mathrm{mg}$, two times per day.

Participant 2 was retired since 1999, she stopped working to take care of her children. She is divorced and at the study period her main responsibilities were home care. She did not require supervision. Her baseline MMSE score was 23 and modified $\mathrm{H}-\mathrm{Y}$ scale was 3.

Participant 2 presented moderate difficulty in taking positions on the force plate, used four moments of rest between trials and she was the only participant to have to repeat a trial due to the movement of the feet during the predicted time. She did not have any discomfort during the intervention.

\section{Participant 3}

Participant 3 was a 53-year-old woman, with a diagnosis of PD made in 2012, with her right side being the more-affected side of the body. Aside from PD, she had no other significant 
medical history. Throughout the course of this study, PD was medically managed with levodopa and benserazide $250 \mathrm{mg}$, three times per day.

Participant 3 is a shopkeeper. Carrying out her activities presented some difficulty due to muscle stiffness. She has two children and also takes care of the home. She did not require supervision. Her baseline MMSE score was 25 and modified $\mathrm{H}-\mathrm{Y}$ scale was 3.

Participant 3 had no difficulty in taking positions on the force plate and used only one period of rest. She did not present any discomfort during intervention.

\section{RESULTS}

All participants were assessed at the same time of day and all were during the on-phase of the medication cycle.

\section{Participant 1}

Participant 1 showed improvement in trunk mobility as indicated by TIS and TMS. Furthermore, there was a slight decrease in the execution time of TUG test, which reflects functional mobility (Table 1).
Table 2 shows postural control data. There was a decrease in the $\mathrm{AP}$ and $\mathrm{ML}$ displacement of the COP in standing posture, that is, the oscillation in both directions decreased. These changes directly influenced the ellipse area, which also decreased. Total velocity of the COP showed little change (decrease). Regarding LOS, participant 1 showed an increase in the LLOS and RLOS. However, for the FLOS and BLOS there was a decrease.

Participant 1 subjectively reported that her mobility significantly improved and she felt lighter after the intervention. She also stated that the knee flexion during walking was immediately easier, moreover there was a decrease of the muscle tension on the upper cervical region, characteristic of PD.

\section{Participant 2}

Participant 2 demonstrated improvement in trunk mobility as indicated by TIS and TMS. Moreover, there was a slight decrease in the execution time of TUG test, as shown in Table 1.

There was an increase in the AP displacement of the COP and a decrease in the ML displacement, i.e., the oscillation

Table 1. Trunk mobility and functional mobility for three participants pre- and post-intervention.

\begin{tabular}{|c|c|c|c|c|c|c|c|c|c|}
\hline \multirow{2}{*}{ Measures } & \multicolumn{3}{|c|}{ Participant 1} & \multicolumn{3}{|c|}{ Participant 2} & \multicolumn{3}{|c|}{ Participant 3} \\
\hline & Pre & Post & $\%$ & Pre & Post & $\%$ & Pre & Post & $\%$ \\
\hline \multicolumn{10}{|l|}{ TIS (score) } \\
\hline SSB & 6 & 7 & 14.29 & 3 & 7 & 57.14 & 6 & 7 & 14.29 \\
\hline DSB & 3 & 7 & 40.00 & 6 & 10 & 40.00 & 4 & 9 & 50.00 \\
\hline $\mathrm{CO}$ & 2 & 4 & 33.33 & 2 & 5 & 50.00 & 4 & 6 & 33.33 \\
\hline TOTAL & 11 & 18 & 30.43 & 11 & 22 & 47.83 & 14 & 22 & 34.78 \\
\hline TMS (score) & 7 & 2 & 23.81 & 14 & 15 & -4.76 & 6 & 4 & 9.52 \\
\hline $\begin{array}{l}\text { TUG } \\
\text { (seconds) }\end{array}$ & 9.06 & 8.87 & & 13.83 & 13.17 & & 9.42 & 9.80 & \\
\hline
\end{tabular}

TIS - Trunk Impairment Scale, TMS - Trunk Mobility Scale, TUG - Timed up and go test (mean of three trials), SSB - Static sitting balance, DSB - Dynamic sitting balance, CO - Coordination, $\%$ - Improvement rate post-intervention.

Table 2. Postural control (COP parameters) for three participants pre- and post-intervention.

\begin{tabular}{|c|c|c|c|c|c|c|}
\hline \multirow{3}{*}{$\begin{array}{c}\text { Measures } \\
\text { AP displacement }(\mathrm{cm})\end{array}$} & \multirow{2}{*}{\multicolumn{2}{|c|}{$\begin{array}{c}\text { Participant } 1 \\
\text { Pre Post }\end{array}$}} & \multirow{2}{*}{\multicolumn{2}{|c|}{$\frac{\text { Participant } 2}{\text { Pre Post }}$}} & \multirow{2}{*}{\multicolumn{2}{|c|}{$\frac{\text { Participant } 3}{\text { Pre Post }}$}} \\
\hline & & & & & & \\
\hline & 2.79 & 2.08 & 1.45 & 2.37 & 1.83 & 2.23 \\
\hline ML displacement $(\mathrm{cm})$ & 2.00 & 1.27 & 1.14 & 0.90 & 0.93 & 1.14 \\
\hline Total velocity $(\mathrm{cm} / \mathrm{s})$ & 0.86 & 0.80 & 0.63 & 0.66 & 0.89 & 0.94 \\
\hline Ellipse area $\left(\mathrm{cm}^{2}\right)$ & 4.12 & 1.66 & 1.44 & 1.80 & 1.29 & 1.94 \\
\hline FLOS $(\mathrm{cm})$ & 14.30 & 15.45 & 11.15 & 10.16 & 10.02 & 10.91 \\
\hline BLOS $(\mathrm{cm})$ & 9.67 & 10.86 & 10.16 & 9.52 & 5.75 & 6.32 \\
\hline RLOS (cm) & 3.66 & 3.55 & 9.29 & 8.63 & 2.58 & 2.45 \\
\hline $\operatorname{LLOS}(\mathrm{cm})$ & 1.87 & 1.73 & 7.87 & 7.15 & 2.27 & 2.58 \\
\hline
\end{tabular}

AP - Anterior-Posterior, ML - Medial-Lateral, ALOS - Forward limits of stability, BLOS - Backward limits of stability, RLOS - Right limits of stability, LLOS - Left limits of stability. As the distance gets smaller $(\mathrm{cm})$ the limits of stability are greater. Displacement, velocity and ellipse area refer to standing posture. 
increased in the AP and decreased in the $\mathrm{ML}$ directions. These changes influenced the ellipse area, which increased. Total velocity suffered a minor change (increase). Participant 2 showed increased stability limits in the four evaluated directions (Table 2).

She subjectively stated that her trunk mobility improved moderately and she felt lighter after the intervention. She also reported improvement in mobility of the feet during gait. Furthermore, the muscle tension on the upper cervical region decreased.

\section{Participant 3}

There was improvement in the trunk mobility identified mainly by TIS. Moreover, participant 3 showed an increase in the execution time of TUG test (Table 1). Table 2 shows that there was an increase in the AP and ML displacement of the COP, that is, the oscillation increased in the two directions. This was reflected in an increased ellipse area. Total velocity suffered a minor change (increase). Participant 3 showed a decrease of the LLOS, FLOS and BLOS and an increase of the RLOS.

Participant 3 reported feeling lighter, her mobility improved significantly and she could easily crouch after the intervention. She also reported that her limbs had moderate improvement of strength when performing the movements. Walking was easier and the muscle tension on the upper cervical region decreased.

\section{DISCUSSION}

Trunk mobility improved in the three participants, according to TIS. Siqueira et al ${ }^{(33)}$ placed emphasis on the improvement of trunk mobility because it is a prerequisite to acquisition of functional independence. Two of the three participants showed improvement in TMS. Perhaps the results were less consistent with this scale because linear movements were individually evaluated, unlike TIS that evaluated functional and combined movements.

There was a decrease in execution time of TUG test for participants 1 and 2. Moreover, ML sway in the static position decreased. Thus, the decrease of COP displacement was reflected in skill improvement and reduced time in the execution of the TUG test. On the contrary, participant 3 showed a time increase on the TUG test as well as an increase in $\mathrm{ML}$ displacement.

Participants 2 and 3 showed an increase of the AP displacement of COP. The displacement velocity of COP and ellipse area presented variation among participants, according to AP and ML sway. The ellipse area covers $95 \%$ of the COP data, and the two axes of the ellipse are calculated from the dispersion measures of COP, i.e., $95 \%$ is how the individual sways within the base of support. ${ }^{(34,35)}$

According to the study by Lopez et al, (17) the AP and $\mathrm{ML}$ displacement of 40 healthy individuals were evaluated before and after an osteopathy protocol applied during three weeks. The results showed an increase of AP displacement of COP, which can be associated with an increase in postural instability. On the other hand, Palmieri et $a^{\left({ }^{(36)}\right.}$ described that a higher velocity and a large total excursion of COP might simply represent the generation of normal active sway to find a stable solution to the postural challenge. In other words, greater sway and velocity do not necessarily mean greater postural instability. Some studies have shown that the decrease in AP sway is a pathological feature of PD, and may cause postural instability. Thus, the increase of this sway could benefit the postural control and mobility of individuals. ${ }^{\text {(37-39) }}$

Regarding the LOS, it is important to note that the smaller the distance between the COP and the edge of the foot $(\mathrm{cm})$, the higher the LOS, i.e, the individual can move easily in one direction without taking his/her feet off the floor. ${ }^{(33,35,40)}$ The results of this study showed a variation in LOS, with improvement in some directions. This improvement may indicate that after intervention the participants felt safe to oscillate at higher amplitudes without this representing instability and risk of falling. Perhaps the intervention improved the mobility of the trunk and this reflected a greater ability to perform the trunk displacements, which influenced the LOS. The greater oscillation in this direction allowed the participants to leave the fixed position characteristic of the disease and move the trunk in AP directions without modifications in base of support, according to Schieppati et $\mathrm{al}^{(37)}$ and Nallegowda et al. ${ }^{(38)}$

\section{CONCLUSION}

The intervention appears more effective and consistent for mobility than stability, although the static stability and LOS did show improvement in some directions. Thus, the intervention performed in this study may cause different responses, especially for postural control. Therefore, it is important to evaluate its application and continuity in each case based on responses related to postural control, trunk mobility and functional mobility over time, performing an intervention directed at problem solving.

Despite the favorable outcomes reported, the study design prevents us from drawing conclusions about the effects of approach in high cervical and occipitomastoid on postural control and mobility of individuals with PD and the results cannot be generalized. The inherent design of any case series must be taken into consideration when reviewing outcomes. Ultimately, the use of a restricted approach to the cervical region may have interfered with the results.

Further studies with a larger sample and a control group are warranted to confirm these outcomes. Future studies should focus on the use of a more complete protocol applied over a long period of time and involving different areas of the body, as well as on analysis of other variables related to stability and movement. 


\section{AUTHOR'S CONTRIBUTION}

A.R.S. - plan and development; data collect e treatment; analysis and interpretation redaction; M.C.S. - data collect e treatment; analysis and interpretation; critical review; C.B.M. - data collect e treatment; analysis and interpretation; critical review; E.C.R. - plan and development; data collect e treatment; analysis and interpretation; redaction; N.T.F. - plan and development; data collect e treatment; analysis and interpretation; critical review.

\section{COMPETING INTERESTS}

The author(s) declare that they have no competing interests.

\section{AUTHOR DETAILS}

${ }^{1}$ Corpore Fisioterapia e Atividade Clinic, Santa Maria (RS) Brazil. 2. School of Physical Education and Sports, Biomechanics Laboratory, Universidade Federal de Santa Maria (UFSM), Santa Maria (RS) Brazil. 3. Physical Education Department, Universidade Federal do Parana (UFPR), Curitiba (PR) Brazil. 4. Espaço Vital Clinic, Santa Maria (RS) Brazil.

\section{REFERENCES}

1. Cersosimo MG, Benarroch EE. Autonomic involvement in Parkinson's disease: Pathology, pathophysiology, clinical features and possible peripheral biomarkers. Journal of the Neurological Sciences. 2012; 1-2(313):57-63.

2. Herman T, Rosenberg-katz K, Jacob Y, Auriel E, Gurevich P, Hausdorff, J. White Matter Hyperintensities in Parkinson's Disease: Do They Explain the Disparity between the Postural Instability Gait Difficulty and Tremor Dominant Subtypes. Plos One. 2013;8(1):1-11.

3. Marusiak J, Jaskólska A, Koszewicz M, Budrewicz S, Jaskólski A. Myometry revealed medication-induced decrease in resting skeletal muscle stiffness in Parkinson's disease patients. Clinical Biomechanics. 2012;27(7):632635.

4. Powwel D, Threlkeld JA, Fang X, Muthumani A, Xia R. Amplitude-and velocity-dependency of rigidity measured at the wrist in Parkinson's disease. Clinical Neurophysiology. 2012;123(4):764-773.

5. Spaulding S, Barber B, Colby M, Cormack B, Mick T, Jenkins M. Cueing and Gait Improvement Among People With Parkinson's Disease: A Meta-Analysis. Archives of Physical Medicine and Rehabilitation. 2013;94(3):562-70.

6. Yarnall A, Archibald N, Burn D. Parkinson's disease. Medicine. 2012;40(10):529-535.

7. Yu H, Sternad D, Corcos D, Vaillancourta D. Role of hyperactive cerebellum and motor cortex in Parkinson's disease. Neurolmage. 2007;35(1):222233.

8. Brusa L, Ceravolo R, Kiferle L, Monteleone F, lani C, Schillacid O, Stanzionef P, Kochf G. Metabolic changes induced by theta burst stimulation of the cerebellum in dyskinetic Parkinson's disease patients. Parkinsonism and Related Disorders. 2012;18(1):59-62.

9. Busquet L. Las Cadenas Musculares. 2006;331:(5) ed, Paidotribro.

10. Marusiak J, Kisiel-sajewicz K, Jaskólska A, Jaskólski A. Higher Muscle Passive Stiffness in Parkinson's Disease Patients Than in Controls Measured by Myotonometry. Archives of Physical Medicine and Rehabilitation. 2010;91(5):800-802.

11. Clarissa RCF, Leão $P$, Townsend R, Rieder CRM. Reliability and validity of a scale for measurement of trunk mobility in Parkinson's disease Trunk Mobility Scale. Arquivos em Neuropsiquiatria. 2011;4(69):636-641.

12. Doherty KM, Warrenburg BPV, Peralta MC, Silveira-moriyama L, Azulay JP, Gershanik OS, Bloem BR. Postural deformities in Parkinson's disease. The Lancet Neurol. 2011;10(6):538-49.

13. Netter FH. Atlas de anatomia humana. 2008;603:(4) ed., Saunders.

14. Paoletti S. The fasciae - anatomy, dysfunction and treatment. 2006;345:(1) ed, Eastland press Inc.
15. Verheyden G, Willems A, Ooms L, Nieuwboer A. Validity of the Trunk Impairment Scale as a Measure of Trunk Performance in People With Parkinson's Disease. Archives of Physical Medicine and Rehabilitation. 2007;88(10):1304-8.

16. Coulbois C, Gauchard GC, Maillard L, Barroche G, Vespignani H, Auque $J$, Perrin PP. Management of postural sensory conflict and dynamic balance control in late-stage Parkinson's disease. Neuroscience. 2011;193(193):363-369.

17. Lopez D, King HH, Knebl JA, Kosmopoulos V, Collins DR, Patterson RM. Effects of Comprehensive Osteopathic Manipulative Treatment on Balance in Elderly Patients: A Pilot Study. J Am Osteopath Assoc. 2011;111(6):382388.

18. Pasman EP, Murnaghan CD, Bloem BR, Carpenter MG. Balance Problems with Parkinson's disease: are They Anxiety-Dependent. Neuroscience. 2011;17(7):283-291.

19. Peotter-nerger M, Reich MM, Colebatch JG, Deuschl G, Volkmann J. Differential Effect of Dopa and Subthalamic Stimulation on Vestibular Activity in Parkinson's Disease. Movement Disorders. 2012;27(10):12681275.

20. Ruget H, Blouin J, Coyle T, Mouchnino L. Modulation of proprioceptive inflow when initiating a step influences postural adjustments. Experimental Brain Research. 2010;201(2):297-305.

21. Su um KJ, Hwang WJ, Yid CW, Fang JJ, Leong IF, Ma um HI. Increasing speed to improve arm movement and standing postural control in Parkinson's disease patients when catching virtual moving balls. Gait and Posture. 2013;3(3):1-5.

22. Tjernstrom F, Fransson PA, Patel M, Magnusson M. Postural control and adaptation are influenced by preceding postural challenges. Experimental Brain Research. 2010;202(3):202-613.

23. Wul T, Hallett M. The cerebellum in Parkinson's disease. Brain. 2013;13(6):696-709.

24. Fabio RPD. Benefits Manipulation of the Cervical Spine: Risks and Benefits. Physical Therapy. 1999;79(9):50-65.

25. Kamali F, Shokri E. The effect of two manipulative therapy techniques and their outcome in patients with sacroiliac joint syndrome. Journal of Bodywork and Movement Therapies. 2012;16(16):29-35.

26. Liem T. Cranial Osteopathy Principles and practice. 2004;(2) ed, German: Elsevier.

27. Brucki SMD, Brucki K, Nitrini R, Caramell P, Bertolucci PHF, Okamoto IH. Sugestões para o uso do mini-exame do estado mental no brasil. Arquivos em Neuropsiquiatria. 2003;61(3):777-781.

28. Schenkman ML. Spinal movement and performance of a standing reach task in participants with and without Parkinson disease. Physical Therapy. 2001;81(7):1400-1411.

29. Castellassia CS, Ribeiro EAF, Fonsecac VC, Beinottid F, Oberge TD, Limaf NMFV. Confiabilidade da versão brasileira da escala de deficiências de tronco em hemiparéticos. Fisioterapia em Movimento. 2009;22(2):189199.

30. Franco CRC, Leão PL, Townsend RC. Rieder Reliability and validity of a scale for measurement of trunk mobility in Parkinson's disease. Arquivos em Neuropsiquiatria. 2011;69(4):636-641.

31. Bischoff HA, Helin HB, Monsch AU, Iversen D, Weyh A, Dechend MV, Akos R, Conzelmann M, Dick W, Theiler R. Identifying a cut-off point for normal mobility: a comparison of the timed 'up and go' test in community-dwelling and institutionalised elderly women. Age and Ageing. 2003;32(3):315-320.

32. Busquet M. As cadeias fisiológicas, a cadeia visceral, tórax, garganta, boca. 2009;282:(7) ed. Manole.

33. Siqueira RMC, Frazão VS, Lopes RSD, Petillo APC. Influência da intervenção fisioterapêutica no controle de tronco em portadores de hemiplegia. 2011;10(3):25-45.

34. Duarte M, Freitas SMSF. Revisão sobre posturografia baseada em plataforma de força para avaliação do equilíbrio. Rev Bras Fisioter. 2010;14(3):183-92. 
35. Barcala L, Colella F, Araujo MC, Salgado ASI, Oliveira CS. Análise do equilíbrio em pacientes hemiparéticos após o treino. Fisioterapia em Movimento. 2011;24(2):337-343.

36. Palmieri R M, Ingersou C D, Stone M B, Krause B A. Center Of Pressure Parameters Used in the Assessement of Postural Control. Journal Sport Rehabilitation. 2002; 11(51):66.

37. Schieppati M, Hugon, Grasso M, Nardone A, Galante M. The limits of equilibrium in young and elderly normal subjects and in parkinsonians. Electroencephalogr Clinical Neurophysiol. 1994;93(4):286-98.
38. Nallegowda M, Singh U, Handa G, Khanna M, Wadhwa S, Yadav SL. Role of sensory input and muscle strength in maintenance of balance, gait, and posture in Parkinson's disease: a pilot study. American Journal of Physical Medicine \& Rehabilitation. 2004;83(12):898-908.

39. Mancini M, Rocchi L, Horak FB, Chiari L. Effects of Parkinson's disease and levodopa on functional limits of stability. Clinal Biomechanics. 2008;23(4):450-458.

40. Soares AV. A contribuição visual para o controle postural. Revista de Neurociências. 2010;18(3):370-379. 